\title{
VERTROUWEN EN ACCOUNTANT
}

\author{
doot Des Jac. P. Slot, lid V.A.G.A.
}

In het Novembernummer van dit maandblad is opgenomen de repliek van Dr Belle op mijn artikel in het Octobernummer getiteld: „Het begrip vertrouwen in Limperg's leer over de grondslagen van de accountantscontrole een ethisch begrip?" In deze aflevering komt bovendien een reactie voor van Drs de Weger op mijn bovenvermeld artikel.

Gaarne maak ik van de gelegenheid, mij door de redactie van het M.A.B. geboden, gebruik om op bovenstaande artikelen te antwoorden.

Het doel van mijn vorig opstel was protest aan te tekenen tegen de wijze, waarop collega Belle de „,vertrouwenstheorie" van Prof. Limperg in zijn artikel in het V.A.G.A.-Jubileumboek heeft gekarakteriseerd. Mijn bedoeling was dus niet om de vertrouwenstheorie zelf aan de orde te stellen. Hierover is reeds veelvuldig van gedachten gewisseld, zodat naar mijn mening een hernieuwde discussie weinig $z$ in heeft.

In mijn dupliek zal ik mij daarom zoveel mogelijk beperken.

Dr Belle ontkent in zijn antwoord, dat hij in zijn Jubileumartikel de theorie van Limperg onjuist interpreteert; het was zijn bedoeling geweest zijn eigen visie op de rol van het vertrouwenselement te geven, doch niet om Limperg's leer nauwkeurig te omschrijven.

Collega Belle gelieve mij deze onjuist interpretatie van zijn opstel wel te vergeven. Doordat Belle zijn visie op het vertrouwenselement onmiddellijk geeft na het noemen van Limperg's vertrouwenstheorie, is het begrijpelijk, dat de lezer veronderstelt, dat Belle's ontboezeming over de citroenen-koopman betrekking heeft op Limperg's vertrouwenstheorie. Het doet mij genoegen te vernemen dat dit niet het geval is. Overigens blijkt uit Belle's repliek in het Novembernummer van dit blad, dat zijn niet aanvaarden van Limperg's leer inderdaad gebaseerd is op een bepaalde interpretatie van die leer. Dit blijkt o.a. duidelijk uit de volgende zinsnede: „...... Ook na deze toelichting (van Prof. Limperg, Sl.) kan ik er geen ",andere dan een ethische inhoud aan verbinden;" ......". (M.A.B. Nov. '52 pag. 429). Belle stelt dus, dat Limperg ten onrechte beweert, dat zijn vertrouwensbegrip geen ethisch begrip is.

Het bezwaar van Belle tegen de vertrouwens-theorie is zuiver gebaseerd op de veronderstelling, dat Limperg een ethisch vertrouwensbegrip bezigt. Ware dit juist, zo ga ik met Belle mede, indien hij zegt, dat men daarop niet een leer kan baseren, die de omvang van de accountants-werkzaamheden aangeeft. Een ethisch vertrouwensbegrip kan inderdaad slechts zijdelings invloed hebben: gij, accountant, zult het vertrouwen dat in U gesteld wordt niet beschamen. Deze ethische regel geldt inderdaad niet alleen voor de accountant, doch evenzeer voor bijvoorbeeld de citroenenkoopman.

Doch Limperg stelt, en heeft in zijn bekende M.A.B.-artikelen ook aangetoond, dat hij dit - ethische - vertrouwensbegrip in zijn theorie niet nodig heeft. Hij ontkent vanzelfsprekend niet, dat bovenvermelde ethische regel ook voor de accountant, en voor hem zelfs in sterke mate. geldt!

Ik moge de lezer wel naar de betreffende artikelen, die ik op dit punt geheel onderschrijf, verwijzen. Hij kan dan zelf beoordelen in hoeverre het bewijs geleverd is!

Belle is van mening dat de omvang van de accountantswerkzaamheden 
wordt bepaald door het doel. Dit is ook naar mijn mening volkomen juist. Het vertrouwen - in ethische zin - laat hij een zijdelingse invloed uitoefenen; een rechtstreekse invloed van het vertrouwen - in ethische zin - wordt door hem terecht ontkend. Doch laat hij nu eens trachten met het begrip verwachting, verwachting n.l. betreffende de te verkrijgen zekerheid, te werken. Niet met verwachting in de betekenis van: „Men verwacht, dat de accountant zijn werk goed zal doen" (natuurlijk verwacht men dat wel!), doch verwachting in de zin van ,men verwacht, dat de accountant een bepaalde zekerheid geeft t.a.v. de juistheid van door hem gecontroleerde gegevens". Hier komt het kwantitatieve element van de verwachting, van het vertrouwen, naar voren. Men vertrouwt, verwacht, bijvoorbeeld niet, dat de accountant de kwaliteit van de op een door hem gecertificeerde balans voorkomende voorraden als expert heeft beoordeeld, doch wel, dat hij zekerheid verschaft over de physieke aanwezigheid van deze voorraden. Dit vertrouwen, deze kwantitatief bepaalde verwachting, ten aanzien van de door de accountant te verschaffen zekerheid, heeft voor de omvang van de docr de accountant te verrichten werkzaamheden toch een bepaalde betekenis! Als de verwachting zich zou wijzigen, als men (ik laat met opzet in het midden wie die, "men" is) zou gaan vertrouwen, dat bijvoorbeeld de accountant als expert instaat voor de kwaliteit van de goederenvoorraad, zou dit op de omvang van de accountantswerkzaamheden van grote invloed zijn (in het hier gegeven voorbeeld zelfs zo, dat betwijfeld moet worden of de accountant voor de alsdan noodzakelijk te verrichten werkzaamheden zich wel de nodige bekwaamheid kan eigen maken).

Collega Belle zal het hier ongetwijfeld mede eens zijn. $\mathrm{Nu}$ is het naar mijn mening dit begrip ,vertrouwen”, dat Limperg gebruikt bij zijn fundering van de contrôleleer, en alle mogelijke andere begrippen, die met het woord ,vertrouwen" worden aangeduid, of zij nu ethisch genoemd moeten worden of niet, hebben met de betreffende leer van Limperg niets uit te staan. Wel natuurlijk met de accountants-practijk: het is evident, dat de accountant, als ieder ander, in zijn handelingen gebonden is aan ethische regels.

Het doel van accountantscontrôle is op zich zelf te onbepaald om te dienen als grondslag voor de bepaling van de omvang van de te verrichten werkzaamheden. Zou uit het doel - het certificeren van een jaarrekening - niet evengoed kunnen voortvloeien, dat de certificerende deskundige nauwkeurig voor de kwaliteit van de voorraden instaat, alsdat dit niet het geval is? De behoefte van het economische leven leert ons hier niets naders. Wel echter het vertrouwen, de verwachting, die , men" op dit punt heeft.

Collega de Weger vraagt zich af of ik het wel zeer zou betreuren, indien Limperg's leer het levenslicht nooit zou hebben aanschouwd. Hij twijfelt daarbij kennelijk aan het practische nut van deze leer. Ik zie de leer van het gewekte vertrouwen als een kompas bij de uitoefening van het accountantsberoep. Vraagt men of het wel zo ernstig zou zijn als het kompas zou ontbreken, dan moet het antwoord luiden: „Dat hangt ervan af waar U vaart en met welk weer $U$ vaart". Vaart $U$ in volle zee dan moet U bij het ontbreken van een kompas andere - minder goede hulpmiddelen te baat nemen. En is het weer dan slecht, dan kunnen die gebrekkige hulpmiddelen falen, waar het kompas $U$ nog redding had kunnen brengen." Overigens heb ik de indruk dat het kompas van de leer van het gewekte vertrouwen ook practisch gebruikt worden door hen. 
die deze leer theoretisch zeggen te verwerpen. Als collega de Weger meent, dat het accountantskompas niet steeds nauwkeurig de weg wijst, dan ben ik het met hem eens; en de oorzaak ligt dan in het feit dat de magnetische pool in de accountantswereld minder bepaald is dan haar geografische zuster. Doch is daarom het magnetische accountantskompas onjuist? (Een niet magnetisch kompas heeft men voor de accountantswereld helaas nog niet uitgevonden!)

Ik ga dus met Collega de Weger mede, als hij zegt, dat de leer van het gewekte vertrouwen niet steeds een voldoende richtsnoer is, bij de bepaling van de omvang van de te verrichten accountantswerkzaamheden. Het principiële belang van het vertrouwen zal hij echter toch niet kunnen ontkennen. Ik geloof ook niet, dat hij dit zal doen. Zijn gedachtengang is naar mijn mening als volgt: "Het vertrouwen is vaak te weinig concreet om als basis te dienen voor een theorie van de accountantscontrôle; een op dat vertrouwen gebaseerde theorie is dus onbevredigend, zodat naar een andere basis gezocht moet worden. Ik geloof echter niet dat een andere basis gevonden kan worden. Prof. Limperg heeft het m.i. juist gezien, als hij in zijn bekende theorie het vertrouwen als uitgangspunt neemt. De enige mogelijkheid voor het vinden van een nauwkeuriger bepaalde basis ligt niet in het zoeken van een andere basis, doch in het meer bepaald worden van die basis. Getracht zal dus moeten worden de verwachtingen, die "men" heeft inzake de door accountantcontrôle te verkrijgen zekerheid nauwkeuriger te bepalen. "Men", dit wil, al naar de omstandigheden, zeggen de opdrachtgevers, het beleggende publiek, de beursinstanties, de fiscus de vakverenigingen, de banken enz., moet zich een meer concrete voorstelling maken van de mate van zekerheid, die zij van accountantscontrôle verwachten. Overleg tussen de accountantsverenigingen die de practische mogelijkheden kunnen beoordelen, en organisaties, die representatief geacht kunnen worden voor het „,publiek" en de omvang van de behoefte aan zekerheid kennen, zal vermoedelijk tot een gunstig resultaat kunnen leiden.

Weet iemand een andere en betere basis te vinden voor een leer omtrent de omvang van een accountantscontrōle dan zal hij het beroep een grote dienst bewijzen. De mogelijkheid daartoe betwijfel ik echter ten zeerste.

Noot van de Redactie: Met de opneming van de artikelen van de heren Drs de Weger en Drs Slot sluiten wij de discussie. 